\title{
TERRITORIAL CAPITAL - A FUZZY POLICY-DRIVEN CONCEPT: CONTEXT, ISSUES, AND PERSPECTIVES
}

\author{
Balázs István Tóth \\ Faculty of Economics, Department of International and Regional Economics \\ University of West Hungary \\ Erzsébet u. 9, H-9400 Sopron: Hungary \\ tothbalazsistvan@gmail.com
}

\begin{abstract}
The interest in the concept of territorial capital has considerably increased in the past few years. The first goal of the study is to give an overview of the possible interpretations and elements of territorial capital. Second, it is aimed at giving a summary of the circumstances that have encouraged the emergence of the territorial capital approach. The third goal is to go beyond the description of current issues by presenting how the concept has been used to verify development issues, while also by highlighting some challenges of empirical investigations on the research topic. Finally, the chances that territorial capital will be used as a strategic planning approach is detailed in addition to a decision support tool. The main result of the study is an own view of the concept of territorial capital which synthesises the up till now state of the research issue and points out its potentials for both scholars and policy-makers.
\end{abstract}

Keywords: territorial capital, conceptual merits, analytical limits, policy perspectives, strategic planning.

\section{Introduction}

Territorial capital has gained considerable attention and is becoming a major field of interest, despite not having a long tradition in regional science, spatial planning, and spatial thinking. The notion of territorial capital and the main motivations for this research issue, along with the characteristic features of territorial capital, are currently being revealed by the scientific community. The main argument for exploring the essence of territorial capital can be underlined by considerations, such as the fact that scholars, as well as practitioners and planners, have hardly any information about why the concept of territorial capital has become relevant in recent years. Although an agreed-upon and unambiguous definition is yet to be formulated, and there is no widespread agreement on the concept of territorial capital, this emerging research issue should be regarded as a decisive and challenging scientific approach with promising perspectives in reshaping decision support techniques in the future.

The study sets four goals, which determine the way the paper is organised. The first is to give an overview of the possible interpretations and elements of territorial capital. Second, it is aimed at giving a summary of the circumstances that have encouraged the emergence of the territorial 
capital approach. The third goal is to go beyond the description of current issues by presenting how the concept has been used to verify development issues, while also by highlighting some challenges of empirical investigations on the research topic. Finally, the chances that territorial capital will be used as a strategic planning approach is detailed in addition to a decision support tool.

\section{The notion and elements of territorial capital}

The term 'territorial capital' was first mentioned in a regional policy context; thus, the concept was introduced outside the realm of science. While the first important contribution was proposed by the LEADER European Observatory (LEADER EO) in 1999, the term was popularised by the Organisation for Economic Co-operation and Development (OECD) in 2001.

In its document, LEADER suggested the following interpretation: "The 'territorial capital' represents all of the elements available to the area, both tangible and intangible, which in some respects constitute assets and in others constraints" (LEADER EO 1999: 19). It was also highlighted that the term refers to resources that "are not part of an accounting inventory exercise, but are intended to identify the distinctive features of an area whose value can be enhanced", and it should not be summed up only in terms of the degree of past sacrifices made to achieve the present stock; therefore, territorial projects based on territorial capital require the analysis of "today's capital" in order to develop territorial development strategies. I share this belief because of events in the past ("history of an area") obviously mirror the accumulation of territorial capital, and the stock of territorial capital under present conditions can even determine future directions ("the territorial project").

In the introduction of Territorial Outlook, the importance of territorial capital was stressed as follows: "Territorial capital refers to the stock of assets which form the basis for endogenous development in each city and region, as well as to the institutions, modes of decision-making and professional skills to make best use of those assets" (OECD 2001: 13). In the document, the term was mentioned fourteen times in total between pages fifteen and twenty-five; however, except for the definition mentioned above, the precise and full understanding of the phenomenon remained very unclear. Moreover, although one may find certain links between the territorial capital and regional disparities, agglomeration economies, specialization, clustering, endogenous growth theories and sustainable development, the relation of these expressions seems to be loosely elaborated and slightly explained in the text.

Besides putting some preliminary interpretations on territorial capital, the cited studies also focused on the elements that can form the basis for territorial capital (Tab. 1).

Notwithstanding, OECD's contribution should be regarded as a major initiative in giving impetus to further investigations into territorial capital. The expression was reiterated by the European Commission (EC) a couple of years later. In its proposal, entitled The Territorial State and Perspectives of the European Union, it was stated that "[e]ach region has a specific territorial capital that is distinct from that of other areas and generates a higher return for specific kinds of investments than for others, since these are better suited to the area and use its assets and potential more effectively" (EC 2005: 3, based on OECD 2001: 15-16). 
Table 1. The components of territorial capital according to LEADER EO and OECD

\begin{tabular}{|l|l|}
\hline \multicolumn{1}{|c|}{$\begin{array}{c}\text { Components of an area's capital } \\
\text { according to LEADER EO (1999) }\end{array}$} & \multicolumn{1}{c|}{$\begin{array}{c}\text { Factors of territorial capital } \\
\text { according to OECD (2001) }\end{array}$} \\
\hline $\begin{array}{l}\text { - Physical resources } \\
\text { - Human resources } \\
\text { - Culture and identity } \\
\text { - Institutions and governance }\end{array}$ & $\begin{array}{l}\text { - Geographical location and size } \\
\text { - Climate and natural conditions }\end{array}$ \\
- Know-how and skills & - Factor of production endowment \\
- Activities and business firms & Agglomeration economies, business incubators, \\
- Markets and external relations & industrial districts, business networks \\
- Image and perception & Traditions, understandings, customs, informal rules, \\
& "untraded interdependencies", solidarity, mutual \\
& assistance, co-opting of ideas (social capital) \\
\hline
\end{tabular}

Source: own construction.

Unfortunately, this definition is ambiguous in at least two ways. On the one hand, the definition includes regions as well as areas but does not go into any more detail concerning about how the notion applies to all economic and spatial units (e.g. nations, regions, agglomerations, settlements, urban and rural areas). On the other hand, the proposal focuses on a measurable economic category, the return on investment, and presupposes a relatively high return on a specific kind of investments. However, the definition does not contain any specifications in terms of the rate of return on investment (Tóth 2015).

As a matter of fact, the roots of the understanding mentioned above can be traced back to earlier interpretations of uneven spatial development. For example, according to Harvey (1982) large-scale investments function as "spatial fixes," whereby "fixing" capital in the geographical space in itself may lead to investments that boost production. Such investments have a certain "territoriality", and the benefits from these investments may indirectly change the position of certain areas compared to others regarding growth and competitiveness. In light of this, Camagni (2016) emphasised that the concept of territorial capital implies that the abstract space becomes a 'place' and a 'territory' encompassing localised competencies, skills, externalities, relationships, values, representation and a set of beliefs, rules, and practices.

Besides the aforementioned proposals, other explanations have also been offered over the past few years. The interpretation of territorial capital as '(a set of) localised assets and resources' (Camagni 2008; Zonneveld \& Waterhout 2010; Perucca 2014), '(the stock of) territorial specificities' (Ventura et al. 2008; Affuso \& Camagni 2010), 'geographically and locally-bounded amenities and conditions' (Capello et al. 2011), 'attraction factors' (e.g. ESPON 2012) and 'local structural elements' (Martinoia \& Pompili 2015) draws attention to the fact that territorial assets should be exploited and actively used in order to promote territorial development and ensure territorial competitiveness.

A great number of studies looked at the possible elements of territorial capital, but this study does not attempt to give a detailed overview of the different structures of the components. I only refer to Camagni (2008) here, who identified several components of territorial capital and argued for arranging components in order, considering two dimensions, rivalry, and materiality ${ }^{1}$. The objective of Camagni's classification was to systemise territorial assets that influence the territorial development and determine competitiveness. He also noticed that the different factors of territorial capital derive from geographical, organisational and cognitive proximity (Camagni 2016). Without a doubt, nowadays, this taxonomy could be regarded as a major study of reference; yet somehow, subsequent 
articles and papers did not manage to put this classification into new perspectives. For Camagni, the potential sources of territorial capital are location factors, which he described not in the form of a list, but in a fairly complete, consistent and coherent combination of territorial assets (Fig. 1).

\begin{tabular}{|c|c|c|c|}
\hline $\begin{array}{r}\text { High rivalry } \\
\text { (private } \\
\text { goods) }\end{array}$ & $\begin{array}{l}\text { Private fixed capital } \\
\text { stock } \\
\text { Pecuniary externalities } \\
\text { (hard) } \\
\underline{\text { Toll goods (excludab.) }} \\
\text { c }\end{array}$ & $\begin{array}{l}\text { Relational private } \\
\text { services operating on: } \\
\text { - external linkages for } \\
\text { firms } \\
\text { - transfer of R\&D } \\
\text { results } \\
\underline{\text { University spin-offs }}\end{array}$ & $\begin{array}{l}\text { Human capital: } \\
\text { - entrepreneurship } \\
\text { - creativity } \\
\text { - private know-how } \\
\text { Pecuniary } \\
\text { externalities } \\
\text { (soft) }\end{array}$ \\
\hline 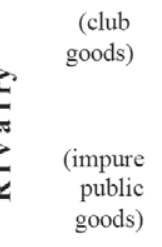 & $\begin{array}{l}\text { Proprietary networks } \\
\text { Collective goods: } \\
\text { - landscape } \\
\text { - cultural heritage } \\
\text { (private "ensembles") } \\
\qquad b\end{array}$ & $\begin{array}{l}\text { Co-operation networks: } \\
\text { - strategic alliances in } \\
\text { R\&D and knowledge } \\
\text { - p/p partnerships in } \\
\text { services and schemes } \\
\text { Governance on land and } \\
\text { cultural resources }\end{array}$ & $\begin{array}{l}\text { Relational capital } \\
\text { (associationism): } \\
\text { - co-operation } \\
\text { capability } \\
\text { - collective action } \\
\text { capability } \\
\text { - collective } \\
\text { competencies } e\end{array}$ \\
\hline \multirow[t]{2}{*}{$\begin{array}{l}\text { (public } \\
\text { goods) }\end{array}$} & $\begin{array}{l}\text { Resources: } \\
\text { - natural } \\
\text { - cultural (punctual) } \\
\text { Social overhead } \\
\text { capital: } \\
\text { - infrastructure } \quad a\end{array}$ & $\begin{array}{l}\text { Agglomeration and } \\
\text { district economies } \\
\text { Receptivity enhancing } \\
\frac{\text { tools }}{\text { Connectivity }} \\
\underline{\text { Agencies for R\&D }} \\
\text { transcoding } g\end{array}$ & $\begin{array}{l}\text { Social capital } \\
\text { (civicness): } \\
\text { - institutions } \\
\text { - behavioural } \\
\text { models, values } \\
\text { - trust, reputation }\end{array}$ \\
\hline & $\begin{array}{l}\text { Tangible goods } \\
\text { (hard) }\end{array}$ & $\begin{array}{l}\text { Mixed goods } \\
\text { (hard + soft) }\end{array}$ & $\begin{array}{c}\text { Intangible goods } \\
\text { (soft) }\end{array}$ \\
\hline
\end{tabular}

Figure 1. The theoretical taxonomy of the components of territorial capital Source: Camagni (2008).

To round off this exploration, from my point of view, territorial capital enables both scholars and practitioners to use a novel approach by taking both material (tangible) and immaterial (intangible) resources of a given territory into account. I define territorial capital as follows: Territorial capital refers to the unity of local (endogenous) resources, which differs in its extent, composition and expedience between territorial units. The term also reflects a portfolio of territorial resources which should be actively utilised to improve the added value of economic units and to strengthen territorial competitiveness. Territorial capital depends on the features and patterns of a territory's economy and society as well as the quality of natural and built environment. In addition, each territory has to find its own specific recipe (strategy) to extract and utilise its territorial capital. 


\section{The roots and context of territorial capital}

When the concept of territorial capital was introduced, regional science and the European regional policy were blossoming in their most exciting epoch. To reveal why the concept of territorial capital emerged, it is necessary to examine the circumstances briefly. I am of the opinion that territorial capital could emerge from at least four conditions.

\section{Shift to endogenous factors and alternative forms of capital}

Considerations of endogenous growth and local capacity building have determined and influenced the appearance of territorial capital (Capello et al. 2011); as a result, concepts and approaches in connection with local values, endogenous resources, and the regional capacity building must be mentioned first. Unlike in earlier times, when factor cost differentials were viewed as the determinants of regional economic development, today the prosperity of territories does not depend solely on material resources, but also on intangible components. Nowadays, a variety of economic, social, environmental and institutional factors, including knowledge, creativity, innovativeness, capacity building, entrepreneurship, human interactions, cooperation and collaboration, social capital etc., is viewed as important intervening local variables and catalysts in the mix of endogenous and evolutionary processes (Stimson et al. 2006; McCann 2013; Capello 2016).

Moreover, since the 1980s, there has been a subtle but fundamental shift in the notion and understanding of capital from being primarily an economic concept towards being a socio-economic one. As a result, an evolution took place in the notion and forms of capital. For instance, sociology and schools of heterodox economic thought, such as ecological economics and institutional economics, as well as knowledge management called attention to the fact that there is a need to invest in alternative forms of capital (e.g. intangible capital, creative capital, intellectual capital, environmental capital, natural capital, relational capital, social capital, cultural capital) to maintain growth and development. Accordingly, territorial development has been closely associated with capital available in a given territory (Kitson et al. 2004; Emery \& Flora 2006; Carayannis et al. 2012). This shift implies that the way certain forms of capital are related to each other is also much more complex than it has traditionally been understood. It is important to recognise that this shift has major implications for how scholars discuss the various elements of growth and development.

\section{Shift in focus on economic planning strategy: from competitive advantage to collaborative advantage}

OECD's Territorial Outlook underlined the importance of regional absolute advantage (based on unique territorial assets) as opposed to the Ricardian comparative advantage (based on the relative costs of the factors of production). In truth, the significance of competitive advantage was highlighted in the OECD document indicating how soft externalities can enhance performance. Moreover, economic development and planning have recently promoted collaborative advantage ${ }^{2}$ (Huxham 1993), thereby encouraging firms and regions to collaborate in competing for strategic advantage, particularly through integrated strategic planning, partnerships, and alliances (Stimson et al. 2006).

Territorial capital and together with its elements based on Camagni's taxonomy are closely associated with both competitive and collaborative advantage: 
- Tangible elements of territorial capital form the basis for overall attractiveness, generate externalities which improve the profitability of local activities, and may be considered as endowments which offer advantage when required;

- Mixed elements of territorial capital allow of long-term efficiency in the economic exploitation of local resources, whilst also strengthening technological transfer and knowledge diffusion;

- Intangible elements of territorial capital support learning and gaining expertise, stimulate knowledge spillovers, reduce transaction costs, and enable collective actions to be taken more easily. Explanations of how regions gain advantages have much in common with the underlying theory of territorial capital. This suggests that a specific set of territorial assets and principles will induce higher economic performance. This approach also implies that there is no way territorial characteristics can be replaced and replicated.

\section{Shift to place-based approach}

Particular interest in the territorial capital has been generated by practical relevance. As both scholars and practitioners have revealed fragile and uneven development between the regions of the $\mathrm{EU}$, the argument for the importance of territorial diversity (Fischer \& Skyes 2009) met with the criticism over the EU cohesion policy (Barca 2009). The ministers' meeting in Luxembourg issued that territorial capital needs to be seen as an important priority to foster a more balanced territorial development. This approach was highlighted in connection with the definition of territorial cohesion suggested by the Assembly of European Regions $(\mathrm{AER})^{3}$ and the agreement proposed after the Informal Ministerial Meeting of Ministers responsible for Spatial Planning and Territorial Development ${ }^{4}$.

Modern place-based arguments clearly acknowledge the role of territorial capital elements in promoting growth and development (Barca 2011), while modern place-based approaches to regional policy emphasise to design policy tools as a mix of hard capital and soft capital (OECD 2009; McCann 2013). Accordingly Zasada et al. (2015) understood place-based development to be the result of investment in the elements of territorial capital (physical capital, human capital, natural capital). Capello (2016) also noticed that the concept of territorial capital is crucial for the appropriate formulation of such policies by highlighting the laws of accumulation and depreciation of all the elements of territorial capital.

\section{Shift to supply-oriented approach}

Local economic development tends to be increasingly focused on supply-side initiatives besides demand-side interventions by addressing issues, such as productivity and investment (Perry 2010). Territorial capital cannot be separated from the shift to supply-oriented approach. In recent years, regional growth theories have evolved noticeably in their interpretation of the concept itself about growth and due to the changes in the production system. The proposal of the OECD (2001) underlined that mass production and consumption systems had changed significantly in an era of "flexible specialisation" when companies can easily relocate activities. Production units seek those locations that provide the highest return on investment at the lowest risk. This interpretation corresponds to the basic notion of territorial capital.

According to Camagni (2008), a more selective pattern of regional growth is emerging, which differentiates among the development paths of the individual regions. Certainly, the 'traditional' resource endowments and location factors ${ }^{5}$ of a city or a region together with the way they 'fit' market conditions are and will be important variables affecting performance; however, the key elements of territorial capital, such as innovative milieu, strategic alliances, external links, agglomeration 
economies, receptivity, and connectivity, have become even more substantial for supporting value addition, enhancing effectiveness, increasing productivity as well as for competing with import industries and developing export-base industries. To ensure this, the investment has to match the competitive and collaborative advantage.

The shift in focus towards the productive capacities of local systems and a sense of well-being derived from greater productive capacities have undoubtedly given way to long-term supply-oriented approaches against short-term demand-oriented processes (Capello 2016).

\section{Current issues and analytical challenges}

It is important to underline that there has been a clear need for conceptualising territorial capital in the past few years. The concept has been introduced into various fields, which means that scholars have different views about what role territorial capital plays. The fundamental concept has undergone changes or at least modifications. On the one hand, scholars established different 'capital frameworks' in order to summarise alternative forms of capital under the term territorial capital. On the other hand, researchers argued for a great variety of multivariate statistical methods in order to test certain hypotheses on territorial capital (In this study, I only refer to examples taken from case studies available in English. For a more detailed overview of territorial capital frameworks and directions of empirical investigations see Tóth 2015.)

Furthermore, the territorial capital approach has been adopted in a variety of spatial contexts. The concept has been used to verify development issues through different case studies. The first empirical investigations using both qualitative and quantitative methods were carried out mainly by Italian scholars citing Italian examples (Perucca 2014; Tortora et al. 2014; Martinoia \& Pompili 2015; Barzotto et al. 2016) and in other macro-regional case studies, concerning among others the Latin Arch regions (Affuso \& Camagni 2010), the Central and Eastern European countries (Fratesi \& Perucca 2014), and the NUTS 2 regions of the European Union (Capello et al. 2011; Camagni \& Capello 2013). In addition, further examples can be found in cases studied in Austria (Giffinger \& Hamedinger 2013), Serbia (Bogdanov \& Janković 2013), Spain (Swagemakers et al. 2014), and the United Kingdom (Lakshmi et al. 2015) etc.; however, these studies did not put the subject into new perspective. While presenting the results of the European Smart Cities research, Giffinger and Gudrun (2010) examined the question as to how the smart city approach may be used as an instrument for raising a city's territorial capital. Recently, a series of investigations into territorial capital has been launched in Poland by the Institute for Development (Instytut Rozwoju) in order to explore the notion of this term (Komornicki \& Zaucha 2015; Zaucha 2015) as well as to analyse the territorial capital of Polish LADs (NUTS 4/LAU 1) (Brodzicki \& Ciołek 2015; Komornicki \& Ciołek 2015). More recently, the intervention of regional policies related to their enhancement was examined in the light of territorial capital through the Polish case (Churski \& Perdał 2016).

Recent works, mostly empirical studies, reflected on the dual elements of:

1. Territorial capital, regional growth and local economic development (Affuso \& Camagni 2010; Capello et al. 2011; Caragliu \& Nijkamp 2012; Camagni \& Capello 2013; Fratesi \& Perucca 2014; Perucca 2014; Brodzicki \& Ciołek 2015; Martinoia \& Pompili 2015);

2. Territorial capital and territorial cohesion (Zonneveld \& Waterhout 2010; Fratesi \& Perucca 2014; Komornicki \& Ciołek 2015; Komornicki \& Zaucha 2015; Zaucha 2015; Churski \& Perdał 2016); 
3. Territorial capital as well as regional and urban competitiveness (Giffinger \& Gudrun 2010; Camagni \& Capello 2013; Giffinger \& Hamedinger 2013);

4. Territorial capital in light of rural development, landscape preservation and community development (Ventura et al. 2008; Copus et al. 2011; Bogdanov \& Janković 2013; Swagemakers et al. 2014; Lakshmi et al. 2015; Zasada et al. 2015);

5. Territorial capital and attractiveness of places (ESPON 2012; Servillo et al. 2012; Tortora et al. 2014);

6. Territorial capital, companies' territorial engagement and local systems (Prezioso \& Coronato 2014; Barzotto et al. 2016);

7. The connection between territorial capital and spatial knowledge spillovers (Caragliu \& Nijkamp 2012).

On a positive note, researchers managed to relate the concept of territorial capital to other themes, yet, research directions may therefore easily become shallow. Now, it seems that this approach provides a reference in general; namely, no matter what topic is discussed, the concept of territorial capital is usually included with reference to a couple of basic works that everybody else has already cited. The various streams, trends and orientations mentioned above are far from establishing a coherent and shared framework for territorial capital, and the overgeneralisation of territorial capital poses threats to the general acceptance of the concept in science.

I appreciate fundamentally that the exploration of territorial capital should be based on a closer analysis of the economic and sociological capital types (human capital, social capital, relational capital, cultural capital, natural capital, etc.), thereby evaluating the resources, growth and development potential of the individual regions. To this end, however, traditional methodological recipes, such as the local transformations of macro indicators, should be set aside. Avoiding too much universalisation is important for scholars to understand the uniqueness of a territory's capital. Attention should be drawn to the unique soft elements of regional and urban development, which make it possible to develop relevant indicators to be used at the local level, irrespective of whether they can be aggregated to higher regional levels. Incidentally, I agree with Zonneveld and Waterhout (2010), who thinks that territorial capital cannot fully be understood in terms of indicators and technological solutions.

In addition, an answer should be provided to the question as for how to estimate intangible capital, which is a quality category rather than quantity category, as well as how intangible capital can be assessed in regional and territorial context. Too much energy is wasted on establishing the criteria for measuring these components on a metric scale despite the fact, that the difference between cultural, social and relational capital cannot be measured on a quantitative basis; what is more, there is no point in interpreting such differences, but the individual and often contradictory attributes of the phenomena that occur in the various regions should be emphasised. In addition, empirical investigations should focus on how strongly the various factors (e.g. indices and indicators) are connected to each other instead of aligning them or analysing them separately. This would also shift the focus on the 'prioritisation' of empirics and accumulation of data towards the development of concepts and approaches in order to reveal new techniques of spatial planning. 


\section{Future perspectives: the chances of territorial capital as a strategic planning approach and a decision support tool?}

It is always important to outline the policy-oriented or practical relevance of a novel approach and concept; thus, the role of territorial capital in strategic planning and the decision-making processes should be mentioned as a final point. Strategic planning usually helps in evaluating performance under changing circumstances as well as building on strength and weaknesses (Stimson et al. 2006). An important feature of strategic planning is that open interpretations may offer clear and common explanations, in other words, during the planning and implementation processes, an appealing new term, such as territorial capital, should make sense.

Without a doubt, the concept is of great importance, but one that has not been refined and evaluated in the necessary depth yet in the policy context. Although territorial capital is still missing from economic development strategies and plans, there are certain hints about it in applied research, planning documents and policy briefs. In fact, local economic development strategies and policy issues have not been organised around the notion of territorial capital yet. To reach this target, the concept of territorial capital should be regarded as an important pillar of spatial planning. The fundamental aspect is to define appropriate strategies for using sources of territorial capital, ensuring their protection and their valorisation in the long run.

OECD (2001) argued for certain links between territorial capital and the emergence of a new paradigm for regional policy, mentioning that territorial development as a policy field is based on the recognition that prosperity is a matter of how cities and regions achieve their potentials. Another important feature of regional strategies is providing solutions for enhancing the regional attributes, and a good starting point for commenting on tangible and intangible factors can be the territorial capital approach.

As presented in the previous sections, the territorial capital approach provides a new classification of endogenous potentials, whilst also suggesting new techniques for strengthening territorial - urban and regional - competitiveness based on local competitive and collaborative advantage. The concept emphasises the binding of inhabitants, firms and communities together and to space where they live and interact. This attitude may also provide a better opportunity to understand how each alternative forms of capital (cultural capital, human capital, social capital, relational capital, etc.) develops over time and in space. The intensification of a unique image of places, which is based on unique endogenous factors, is essential. However, "[r]egions do not require the presence of all the above components of territorial capital to develop and maintain over time a positive and dynamic development trajectory. The local endowment of specific assets of territorial capital results from the history of the local area, and determines its productive specializations on which a strategic growth pattern is to be built" (Capello 2016: 467).

Without a doubt, future directions for regional economic strategies require the development of additional and alternative tools to support analysis of territorial development and competitiveness on the one hand and to manage economic and social development on the other (Stimson et al. 2006). It is worth noting that decision-makers argue for prognosis tools rather than current or prospective black box models and approaches. Path setting and analysing futures are two major issues that have recently become a major field of interest as attention has turned to consider how regions might position themselves to be competitive with their territorial attributes of rapid change. Obviously, many regions are not re-equipping themselves fast enough to compete sufficiently, since they are not aware of their territorial capital. Accordingly, without understanding territorial capital, forecasting 
tools have to endure the state of uncertainty in a world of resilience and decision-makers may not understand what they really calculate in the present.

At least, the further steps have to be taken into account when identifying and accomplishing of all important actions in view of territorial capital:

1. Scan the endogenous factors of development. It involves a conduct of comprehensive audit of all aspects and factors of the internal environment.

2. Recognise various options that can be used to mobilise the endogenous factors of development. The process helps to find out a thorough theoretical and empirical analysis of interdependencies between the identified endogenous factors within space and time. It may cover both strengths and weaknesses with regard to their evolution and the likely future, as well as the aspirations, expectations, needs, and preferences of local actors with regard to each factor;

3. Decide in which way(s) it is worth investing in the development of endogenous factors of importance with regard to the following:

a. Expected expenditures of investment $(A)$ of actions;

b. Expected benefits or profits (B) of investment;

c. Expected return of investment (B/A);

4. Develop concrete goals, strategies, and actions with respect to advantageous (beneficial) investments. This process also involves the decision over implementation and monitoring.

This way of thinking harmonises the definition provided by the OECD (with respect to return on investment) and Camagni's view on the taxonomy on territorial capital (with respect to the endogenous factors of development). If practitioners and planners argue for the territorial capital approach, exploration, and analysis, positioning as well as formulating a vision and setting the objectives should be based on the concept of territorial capital, which helps them to strengthen the role of collaborative advantage as well as local partnerships and networks in regional economic development strategy and planning. The territorial capital approach should also be used for evaluation, update, and monitoring. It also needs to be interactive and continuing over time in the course of feedback.

The development of decision support tools can be revisited and reshaped based on this approach. Certainly, it is not a new paradigm, but as mankind reaches a new age in which human capital, relational capital, social capital and other elements of smart infrastructure grow in importance in spatial planning and spatial thinking, it will be crucial that strategies are designed in consideration of the components of the 'territorial capital matrix'. In other words, the approach may provide an overview for identifying and accomplishing the most important actions and directions of forthcoming investments in view of the classical and alternative notions of capital.

\section{Conclusions: limits and merits of the research issue}

Although the concept of territorial capital has not yet become influential in debating the scholarly discourse in regional science, and, much of the investigations have been mono-disciplinary, the idea draws attention to the importance of a new classification of territorial assets that is highly attractive to scholars.

Unfortunately, without a few exceptions (see e.g. Tóth 2015), the approach has not attracted criticism. Certainly, the concept could be criticized on more theoretical grounds, especially within the mainstream economics; but the main limit of the research topic is of an analytical-empirical nature. As the empirical studies suggest, territorial capital cannot be measured using one indicator 
only. Instead, several factors should be included in multivariate statistical analyses, which can be very diverse with regard to the system of indicators and the applied methodologies. Currently, it seems that no consensus exists over the system of possible indicators, mainly because there are considerable differences in how scholars have been 'acclimatised' in different contexts and how they theorise territorial capital.

Still, it is worthwhile to point out some of its merits. The most notable achievement of the concept of territorial capital is that it subsumes the set of territorial assets under a synthetic notion. The fuzzy notion of territorial capital is not a problem per se because the loosely defined phenomenon can be used to produce a rough insight into economic and social trends. Another considerable merit is the reintegration of territorial factors into the analysis of regional and urban development. Furthermore, the research topic has to face the challenges of European economic and territorial development policies, while partly also contributing to the new debate about regional policy. The place-based approach assumes in particular that unique territorial characteristics and some of the various dimensions of regional 'capital' are largely immobile (McCann 2013). Planners and practitioners should become aware of the situation that capital cannot be profoundly mobile since certain (mainly alternative) forms of it are "tied down" in concrete places and processes. The set of conditions available in a given territory cannot be mobilised and relocated simply.

In keeping with the aims presented in the introduction, this study evaluated the up till now state of the research issue and pointed out its potentials for both scholars and policy-makers. Obviously, territorial capital has been introduced to various fields, and researchers argued for a great variety of themes and spatial contexts to take in-depth look at the different aspects of territorial capital. However, the term has not been refined and evaluated in the necessary depth yet in the policy context; as a result, it is still missing from economic development strategies and plans.

My findings may contribute to a better and clear understanding of territorial capital. In my experience, territorial capital refers to the unity of local (endogenous) resources, which differs in its extent, composition and expedience between territorial units, and depends on the features and patterns of a territory's economy and society as well as the quality of natural and built environment. Accordingly, attention should be drawn to the unique elements of regional and urban development and competitiveness. Consequently, the possible ways for measuring territorial capital should be built upon the direct observation of economic, social and environmental phenomena in their territorial settings, for instance, in form of a field research mixed with advanced modes of quantitative methods, such as factor analysis, cluster analysis, multidimensional scaling, or path analysis.

Although the concept of territorial capital opened a new phase in the discourse about the endogenous factors of regional development, the approach has remained as fuzzy as it was a couple of years ago. Although it seems difficult, it is not impossible to develop and entrench a common vision for the valorisation of territorial capital in spatial planning. Borrowing from Arthur Schopenhauer, "the task is not so much to see what no one has yet seen, but to think what nobody yet has thought about that which everybody sees". Introducing a new term in regional science can mean doing something entirely new, but it can also mean making a new combination of things that already exist. The latter is true in terms of territorial capital. My last conclusion is that this term has, at this juncture, great potentials for providing fresh perspectives for both scholars and practitioners in regional science and spatial thinking. 


\section{Notes}

1. Rivalry makes it possible to identify whether the elements of territorial capital can be used only by an individual (private goods) or by a specific group of people (impure public goods, club goods), or are available to the whole community (public goods). Materiality helps identify a good according to its physical or intangible nature tangible goods, intangible goods, and an intermediate class of mixed goods (Camagni 2008). Zonneveld and Waterhout (2010) noticed that territorial capital is not only a matter of so-called 'hard' territorial characteristics but also, and probably even more so, a matter of 'soft' social-cultural features.

2. According to Huxham, "[c]ollaborative advantage is concerned with the creation of synergy between collaborating organizations. Collaborative advantage will be achieved when something unusually creative is produced - perhaps an objective is met - that no one organization could have produced on its own and when each organization, through the collaboration, is able to achieve its own objectives better than it could alone" (Huxham 1993: 603).

3. The Assembly of European Regions (AER) mentioned territorial capital in the context of territorial cohesion: "Territories developing harmoniously and in synergy with each other, heading to common priorities and objectives, by implementing strategies with means and tools adapted to their territorial capital, providing an equal access to services and opportunities for all European citizens" (AER 2008: 18).

4. The Territorial Agenda of the European Union 2020 documented that „,[p]laces can utilize their territorial capital to realise optimal solutions for long-term development, and contribute in this way to the achievement of the Europe 2020 Strategy objectives" (Territorial Agenda... 2011: 4).

5. 'Traditional' resource endowments refer to a static interpretation of factors affecting the location of a business, such as availability of raw materials, natural advantages, amenities and infrastructure, proximity to labour markets and consumer markets, as well as image and safety of the place.

\section{References}

Affuso A., Camagni R., 2010. Territorial capital and province performance in the Latin Arch: an econometric approach. Milan: Italian Association of Regional Sciences.

Assembly of European Regions (AER), 2008. AER Contribution to Green Paper on Territorial Cohesion. Wroclaw: Adopted on 11th June 2008 AER Bureau Meeting.

Barca F., 2009. An Agenda for a Reformed Cohesion Policy. A Placed-based Approach to Meeting European Union Challenges and Expectations. Independent Report Prepared at the Request of the European Commissioner for Regional Policy. Danuta Hübner. Brussels: European Commission.

Barca F., 2011. Alternative Approaches to Development Policy: Intersections and Divergence. OECD Regional Outlook 2011. Building resilient regions for stronger economies. Paris: OECD, pp. 215-225.

Bogdanov N., Janković D., 2013. Territorial Capital of Rural Areas: An Example of Analysis of the Potential for Rural Tourism Development in Serbia[in:] D. Škorić, D. Tomić, V. Popović (eds.), Agri-Food Sector in Serbia. State and Challenges. Belgrade: Serbian Association of Agricultural Economics, pp. 201-232. 
Barzotto M., Corò G., Volpe M., 2016. Territorial capital as a company intangible. Exploratory evidence from ten Italian multinational corporations. Journal of Intellectual Capital, vol. 17, no. 1 , pp. 148-167.

Brodzicki T., Ciołek D., 2015. Territorial Capital and Polish Regional Development. Institute for Development Working Papers, no. 011/2015, Sopot: Institute for Development.

Camagni R., 2008. Regional Competitiveness: Towards a Concept of Territorial Capital. [in:] R. Capello, R. Camagni, B. Chizzolini, U. Fratesi (eds.), Modelling Regional Scenarios for the Enlarged Europe. European Competitiveness and Global Strategies. Berlin-Heidelberg: Springer, pp. 33-46.

Camagni R., 2016. Towards Creativity-Oriented Innovation Policies Based on a Hermeneutic Approach to the Knowledge-Space Nexus [in:] A. Cusinato, A. Philippopoulos-Mihalopoulos (eds.), Knowledgecreating Milieus in Europe. Berlin-Heidelberg: Springer, pp. 341-358.

Camagni R., Capello R., 2013. Regional Competitiveness and Territorial Capital: A Conceptual Approach and Empirical Evidence from the European Union. Regional Studies, vol. 47, no. 9, pp. 1383-1402.

Capello R., 2016. Regional Economics. London-New York: Routledge.

Capello R., Caragliu A., Nijkamp P., 2011. Territorial Capital and Regional Growth: Increasing Returns in Cognitive Knowledge Use. Tijdschrift voor Economische en Sociale Geografie, vol. 102, no. 4, pp. 385-405.

Caragliu A., Nijkamp P., 2012. The Impact of Regional Absorptive Capacity on Spatial Knowledge Spillovers: the Cohen and Levithan model revisited. Applied Economics, vol. 44, no. 11, pp. 1363-1374.

Carayannis E.G., Barth T.D., Campbell D.F.J., 2012. The Quintuple Helix Innovation Model: Global Warming as Challange and Driver for Innovation. Journal of Innovation and Entrepreneurship, vol. 1, no. 2, pp. 1-12.

Churski P., Perdał R., 2016. Where Do Cohesion Policy Funds Flow and Do They Have any Impact? The Polish Lesson. Barometr Regionalny, vol. 14, no. 3, pp. 7-24.

Copus A.K., Shucksmith M., Dax T., Meredith, D., 2011. Cohesion Policy for rural areas after 2013. A rationale derived from the EDORA project (European Development Opportunities in Rural Areas) - ESPON 2013 Project 2013/1/2. Studies in Agricultural Economics, vol. 113, no. 2, pp. 121-132.

Emery M., Flora C., 2006. Spiraling-up: Mapping Community Transformation with Community Capital Framework. Journal of Community Development Society, vol. 37, no. 1, pp. 19-35.

European Commission (EC), 2005. The Territorial State and Perspectives of the European Union. Towards a Stronger European Territorial Cohesion in the Light of the Lisbon and Gothenburg Ambitions. First Draft. Brussels: European Commission.

ESPON, 2012. ATTREG. The Attractiveness of European Regions and Cities for Residents and Visitors. Final Report. Applied Research 2013/1/7. Luxembourg-Tarragona: ESPON-Univeristy of Rovira i Virgili.

Fischer T.B., Skyes O., 2009. The Territorial Agenda of the European Union. Progress for Climate Change Mitigation and Adaption? The Town Planning Review, vol. 80, no. 1, pp. 57-82.

Fratesi U., Perucca, G., 2014. Territorial Capital and the Effectiveness of Cohesion Policies: an Assessment for CEE Regions. Investigaciones Regionales - Journal of Regional Research, vol. 29, pp. 165-191.

Giffinger R., Gudrun H., 2010. Smart Cities Ranking: an Effective Instrument for the Positioning Cities? Architecture, City and Environment, vol. 4, no. 12, pp. 7-25. 
Giffinger R., Hamedinger A., 2013. Borders in Metropolitan Development: The Case of Vienna. Journal of Borderlands Studies, vol. 28, no. 2, pp. 205-219.

Harvey D., 1982. The Limits to Capital. Oxford: Blackwell.

Huxham C., 1993. Pursuing Collaborative Advantage. Journal of the Operational Research Society, vol. 44, no. 6 , pp. 599-611.

Kitson M., Martin R., Tyler P., 2004. Regional Competitiveness: An Elusive yet Key Concept? Regional Studies, vol. 38, no. 9, pp. 991-999.

Komornicki T., Ciołek, D., 2015. Measurement of Territorial Cohesion. Defining the Measures of Measurable Aspects of this Concept. The Case of Poland. Institute for Development Working Papers. No. 012/2015. Sopot: Institute for Development.

Komornicki T., Zaucha J., 2015. Territorial Cohesion in Polish Regional Development Policy. The Results of Surveys and In Depth Inquiries Covering Regional Authorities in Poland. Institute for Development Working Papers. No. 013/2015. Sopot: Institute for Development.

Lakshmi G., de Zeeuw G., Vahl M., Vilalta-Perdomo E., 2015. Making Friends with Windmills: Building Territorial Capital. Journal of Finance and Risk Perspectives, vol. 4, no. 4, pp. 100-108.

LEADER European Observatory (LEADER EO), 1999. Territorial competitiveness. Creating a territorial development strategy in light of the LEADER experience. Part 1. LEADER European Observatory "Rural Innovation" Dossier No. 6., Brussels.

Martinoia M., Pompili T., 2015. Building synthetic indicators for aspects of territorial capital. Liuc Papers 290, Serie Economia e Impresa 78. Castellanza: Università Carlo Cattaneo.

McCann P., 2013. Modern Urban and Regional Economics. Oxford: Oxford University Press.

Organisation for Economic Co-operation and Development (OECD), 2001. Territorial Outlook. Paris: OECD.

Organisation for Economic Co-operation and Development (OECD), 2009. Regions Matter: Economic Recovery, Innovation and Sustainable Growth. Paris: OECD.

Perry M., 2010. Controversies in Local Economic Development. Stories, Strategies, Solutions. Abingdon-New York: Routledge.

Perucca G., 2014. The Role of Territorial Capital in Local Economic Growth: Evidence from Italy. European Planning Studies, vol. 22, no. 3, pp. 537-562.

Prezioso M., Coronato, M., 2014. Entrepreneurship and Territorial Behavior. How to Exercise Competitiveness in Sustainability in Europe. Social Sciences, vol. 3, no. 1, pp. 28-45.

Servillo L., Atkinson R., Russo A.P., 2012. Territorial attractiveness in EU urban and spatial policy: a critical review and future research agenda. European Urban and Regional Studies, vol. 19, no. 4, pp. 349-365.

Stimson R.J., Stough R.R., Roberts B.H., 2006. Regional Economic Development. Analysis and Planning Strategy. Berlin-Heidelberg: Springer.

Swagemakers P., Rodríguez D.C., García M.D.D., Fernández X.S. 2014. Fighting for a future: an actororiented planning approach to landscape preservation in Galicia. Geografisk Tidsskrift - Danish Journal of Geography, vol. 114, no. 2, pp. 109-118.

Territorial Agenda of the European Union 2020. Towards an Inclusive, Smart and Sustainable Europe Diverse Regions, 2011. Agreed at the Informal Ministerial Meeting of Ministers responsible for Spatial Planning and Territorial Development on 19th May 2011 Gödöllö, Hungary.

Tortora M., Randelli F., Romei P., 2014. A Conceptual Framework for Tourism Transition Areas Based on Territorial Capital: a Case Study of Vinci. Journal of Tourism \& Hospitality, vol. 3, no. 3, pp. 1-11. 
Tóth B.I., 2015. Territorial Capital: Theory, Empirics and Critical Remarks. European Planning Studies, vol. 23, no. 7, pp. 1327-1344.

Ventura F., Brunori G., Milone P., Berti G., 2008. The Rural Web: A Synthesis. [in:] J. D. van der Ploeg, T. Marsden (eds.), Unfolding webs: The dynamics of regional rural development. Assen: Van Gorcum, pp. 149-174.

Zasada I., Reutter M., Piorr A., Lefebvre M., Paloma S.G.y., 2015. Between capital investments and capacity building - Development and application of a conceptual framework towards a placebased rural development policy. Land Use Policy, vol. 46, pp. 178-188.

Zaucha J., 2015. Key Dimensions of Territorial Cohesion. A Review of The Existing Sources of Information on Territorial Cohesion. Institute for Development Working Papers. No. 008/2015. Sopot: Institute for Development.

Zonneveld W., Waterhout B., 2010. Implications of territorial cohesion: an essay. Paper presented at the Regional Studies Association Annual International Conference, May, Pécs, Hungary.

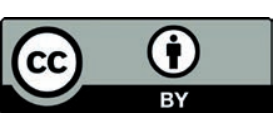


